\title{
Was There Federalism in the Brazilian Empire? A Case of Contrast Between Federal State and Federalism in $19^{\text {th }}$ Century
}

\author{
Leonam Liziero \\ Correspondence: Leonam Liziero, Professor - PPGCJ/UFPB e DCJ/UFPB, Brazil. \\ Received: October 28, 2019 \\ doi:10.11114/ijlpa.v2i2.4646 \\ Accepted: December 12019 Online Published: December 6, 2019 \\ URL: https://doi.org/10.11114/ijlpa.v2i2.4646
}

\begin{abstract}
This article aims to demonstrate that there were federative relations during the Empire of Brazil, with some reform during the regency period. The methodology used to measure the results focuses on the use of bibliographic sources from the 19th century and from more recent studies on the scope of the article. In addition, the use of documentary sources is present, since legislation of nineteenth-century Brazil is used, in particular, the Additional Act of 1834, which gives name to the present work. Although expressly provided for in the 1824 Political Charter that Brazil would constitute a Unitary State, in practice the increased regional concentration of political power led to a functioning situation such as a decentralized federal State. To this end, it begins with a brief demonstration of the antecedents of the Constitution of 1824. It then proceeds to treat the provision of this Constitution about the political organization to finally discuss the effects caused by the Additional Act of 1834.
\end{abstract}

Keywords: Federalism, Federal State, Brazilian Empire, additional act of 1834, constitution of 1824

\section{Introduction}

It is necessary to start the discussion with a brief question of an epistemological matrix: only of connected, federal state and federalism are distinct objects. In 1952, with the publication of A Note on a Nature of Federalism, William Livingston deconstructs the formalist understanding of federalism and proposes a sociological approach. Geographic diversity will be determining, according to Livingston, for social heterogeny. Thus, the geographical concentration of a given population will generate some social cleavages, which make up a notion of belonging to the space in which they live. Livingston calls this phenomenon territoriality.

The diversity generated by such social cleavages is reflected in the political institutions of the State, and especially in the federal ones, formed by Constitutional Law and the object of the legal approach. Such federative institutions are, in each case, the result of a political arrangement. The stability of a country is a longed for ideal, but often far from satisfactory in practice. Thus, constitutional standards, such as the federative form, may not be adequate or effective, with impacts on a possible quality of federalism in each State.

Brazil is a country characterized by its high intricacy in political matters. The constitutional history, for example, seems a paradox. In addition, the federalism's development, as well as the consolidation of federal State, reflect its comprehension's problems.

It is possible to establish is a starting point for this essay the effective date of Constitution of Brazilian Empire, bestowed on February 24, 1824. It marks the beginning of Constitutional State in Brazil. Although the Brazilian Empire it was a Unitary State, the discussion about federalism was present in Constituent Assembly of 1823, this dissolved by Emperor D. Pedro I of Brazil. Even before his Constitution, the Brazilian territory was divided many times, as Hereditary Captaincies and, after, Provinces. This division promoted the emergence of a possible federalism during the colonial age.

The Brazilian federalism precede its Constitutional Law, but the starting point was the Constitution of 1824, who prescribed Brazil as a Unitary State. Indeed, the Federal State merely emerged with promulgation of the First Republican Constitution in 1891. However, federalism was present in several moments during the Empire, betwixt 1824 and 1891.

For the purposes of this paper, I will consider Livingston's proposal, which consists in understanding federalism as a sociological phenomenon. In his article of 1952, Livingston proposes an interesting question: federalism is not 
contained in constitutional law, but in their society ${ }^{1}$. Thus, what would make a state federal would not be the provision of its Constitution, but the configuration of its population in its territory.

Livingston's theoretical provocations directly influenced an understanding that Brazilian federalism is strongly dissociated from its federal state, which is currently foreseen in the Constitution of 1988. Thus, when studying the federal institutes, such as the division of competences, one perceives the highest distance between constitutional prediction and constitutional reality ${ }^{2}$, characteristics of the so-called countries of peripheral modernity, endowed with a nominalist Constitution ${ }^{3}$.

One of the issues that demonstrate this distancing between federalism and federal State in Brazil is precisely the problem of decentralization. Although the movement was politically decentralizing before the Constitution of 1988 was promulgated, the result was a constitution that continued the high concentration of power in the Union, to the detriment of the federated States ${ }^{4}$.

Paradoxically, like many things in Brazil, during a certain period of the Empire, still in the nineteenth century, Brazil functioned almost as a federal State in practice, even though it was formally a unitary state. It is on this point that you will address this present work in the development that follows.

\section{Before 1824}

The republican ideals come from $18^{\text {th }}$ Century, as well as specific problems in Colony, made possible the happenings of $19^{\text {th }}$ Century in Brazil, like its elevation to kingdom, during the United Kingdom of Portugal, Brazil and the Algarves, formed in 1815. Unlike the process of independence of Spanish America, which resulted in several small republics, Brazilian thought was based on maintaining unity in a vast and diversified territory. The monarchy, an institution maintained with Independence in 1822, symbolized the ideal of political and economic stability present in Brazilian society since the time of the State of Brazil (1548-1815).

It was evident in the dispute between the groups that dominated the Brazilian politics, divided between those that defended the return to the Portuguese sovereignty and those that defended the independence of Brazil, that it was necessary the elaboration of a Constitution that could attend the interests of those groups, especially in the that referred to the limitation of the emperor's power. Moreover, the concern of the slaveocratic elites responsible for the slave trade between continents was a great concern that the independence of Portugal could mean the extinction of the viability of their businesses.

The liberal group, whose great icon was José Bonifácio de Andrada e Silva, was responsible for organizing the movement known as "Stay Day" on January 9, 1822 and acted predominantly in the press of the Empire's capital, in the gazettes Reverbero Constitucional Fluminense and Correio do Rio de Janeiro. In addition, the group dominated the Masonic lodges Grande Oriente do Brasil, which played an active role in the Independence process.

Led by José Bonifácio, the group succeeded in winning the Constituent Assembly, convened in 1823, with a project of a centralizing monarchy. On May 3 of that same year, the Constituent Assembly was inaugurated, in which the Emperor declaimed a speech defending the interests of the Crown, who is knowing as Fala do Trono (Thrones' Speaking).

The Assembly consisted of ninety representatives from fourteen provinces. José Bonifacio's group advocated political centralization, with political tendencies in line with those of the Emperor, while calling for freedom of worship and other issues that challenged the traditional approach of state and church, of temporal and spiritual power, defended by the most conservative elites and the Catholic Church itself in Brazil.

The main points of the draft Constitution was presented to the Emperor on September 1, 1823. Some of the main proposals can be highlighted here: (a) the establishment of a hereditary monarchy; (b) executive, legislative and judiciary powers; (c) the legislative power would be bicameral, composed of the House of Representatives and Senate these two chambers, besides the Emperor, would have the power to propose bills and approve or not, authorize loans and fix the budget of the armed forces; (d) Senators and Representatives would be inviolable with regard to their views and the parliament would be inviolable as an institution, and the Emperor could not suspend or close his activities, but could only postpone his activities; (v) the Emperor's right to veto would be suspensive only; (vi) the existence of a State Council; (vii) census suffrage; (viii) indirect elections.

\footnotetext{
${ }^{1}$ Livingston, W. S. (1952). A Note on the Nature of Federalism. Political Science Quarterly, Vol. 67, No. 1, p. 81-95.

${ }^{2}$ Neves, M. (2018). A Constitucionalização Simbólica. 3 ed. São Paulo: Martins Fontes, p. 83-86.

${ }^{3}$ Neves, M. (2018). Constituição de Direito na Modernidade Periférica. São Paulo: Martins Fontes, p. 91.

${ }^{4}$ Liziero, L. (2017). Por um Estado Federal Assimétrico. Insigth Inteligência. Rio de Janeiro, v. 78, p. 132-152.
} 
Conflicts between elite sectors and José Bonifácio led to his departure from the Ministry, which generated a liberal opposition to the Emperor. The Constituent Assembly had its disagreement with the monarch aggravated and such situation culminated in its dissolution on November 12, 1823. The dissolution of the Constituent Assembly set up an historical episode known as "night of agony." The Emperor Peter I ordered the invasion to the plenary and the army arrested some deputies.

The decree that dissolved the Constituent Assembly was intended to present a more liberal constitutional bill, but there was no submission to another assembly for fear of non-approval. The Council of State, instituted the day after the dissolution of the Constituent Assembly, drafted the constitutional text. The bill would later be submitted to the Senate for approval. However, Peter I decided to grant it directly.

The Political Constitution of the Empire of Brazil, of March 25, 1824, brought a four-partitioning of powers, inspired by the model idealized by Benjamin Constant. In addition to the executive, legislative and judicial powers, the moderator power was exercised exclusively by the Emperor and was intended as a locus of neutrality to harmonize conflicts between the other powers.

This is an interesting question in constitutional prediction. From its Article 9, the 1824 Charter prescribes that division, as well as the harmony of powers, is the conservative principle of citizens' rights as well as the most effective means of securing the guarantees offered by the Constitution. The four powers would be delegations of the Nation, which in the language of this Constitution, is the association of all Brazilian citizens.

From Article 98 the 1824 Constitution deals with the moderator power. This power, as the text prescribes, is the key to all political organization and is delegated privately to the Emperor. As its first representative (in the sense of princeps inter pares), the Emperor should ensure the independence and harmony of the other three powers.

Just to make clear the functions of the moderator power, it is worth highlighting the few (but significant) attributions that the 1824 Constitution gave it: (I) appointment of Senators; (II) Extraordinary convocation of the General Assembly; (III) Sanction of decrees and resolutions of the General Assembly, so that they had the force of law; (IV) Approval and suspension of resolutions of Provincial Councils; (V) In the name of the salvation of the State, extend the General Assembly and dissolve the Chamber of Deputies, calling another; (VI) Free appointment and dismissal of Ministers of State; (VII) Suspension of Judges; (VIII) Remission and mitigation of doomed sentences; (IX) Grant of amnesty.

The moderator power is an addition to the doctrine of separation of powers present in Montesquieu's magnum opus. Despite the pretense of neutrality, praxis showed that it was an institutionalized way for the Emperor to exercise control over the other powers as a spark of eighteenth-century absolutism, embodied in the Iberian tradition.

\section{The Legal Unitary in the Constitution of 1824}

The unitary State that was the Empire of Brazil contrasted with the geopolitical scenario of the rest of South America. In addition to be the only State that remained monarchical for many years after Independence, its centralizing administrative structure was in the opposite direction to the young sovereignties, as elucidated Tavares Bastos. According to this author, geographical accidents, climatic conditions and the formation of society on the American continent competed to make centralizing and absolutist states impossible to the mold of Europeans. The administrative organization, which sought a resemblance to the French system, was "a European vice in our administration".

The constitutional provision for the division of territory into provinces originates from the transformation of former captaincies by the Cortes Geraes Extraordinárias in 1821. The Article 2 of the Constitution of 1824 prescribed such division. The provinces did not have autonomy. A President appointed by the Emperor (Article 165) and the General Provincial Councils (Article 72) directly exercised the government of these Provinces. These Councils, despite being foreseen as a body of the legislative power, did not have the power to legislate. Its powers were limited to the discussion and formation of bills of local interest (Article 81) and submission to vote at the General Assembly (Article 85).

Tavares Bastos seemed to misunderstand a provincial president not elected by the people or the provincial assembly, as a direct interference of the central power in local affairs. This caused a certain disarticulation at the local level, especially after the Reform of 1834 , since the legislative power was present at the provincial level, but the executive did not. The Constitution of the Empire of Brazil established that the exercise of legislative power (and, consequently, lawmaker competence) is the exclusive responsibility of the General Assembly (Articles13 and 15), formed by the Chamber of Deputies and Senate (Article 14).

About the main function of legislative power in Brazil Empire, write the Marquis of Caravel, Pimenta Bueno:

To make the law is to prescribe the norms, the precepts that should govern men and things,

${ }^{5}$ Tavares Bastos, A. (1870). A Provincia: estudo sobre a Descentralisação no Brazil. Rio de Janeiro: B.L.Garnier. 
the authorities and society in all their relations; it is to exercise the high faculty of regulating all social forces, their involvement, public destinies, the prosperity or misfortune of the country, for the fortunes of the State depend more than much upon their own laws ${ }^{6}$.

Provinces was not federative unity. Its function was merely to be an administrative division for better territorial control, as present in many unitary and monarchic states until that time, as well as in France with the monarchical Constitution of 1791 and Constitutional Act I, which legally inaugurated the First French Republic.

About this French Constitution, the first writing of Europe, Gilissen ${ }^{7}$ (1995) notes that, while retaining the King's power, it limits them considerably. It also introduced for the first time in France the separation of powers, although in a much less limited way than in the United States. This first French Political Charter served as inspirations for other European monarchical constitutions, like the Portuguese Constitution of 1821.

The State of Imperial Brazil can be understood imagetically by the division of the models of political organization proposed by Elazar ${ }^{8}$ (1997), as a pyramidal model, proper to the unitary states. In this model, the exercise of politics structures itself in hierarchy, with delegation of central power for agents to act on their behalf in localities.

According to the Imperial Constitution, Presidents appointed by the Emperor exercised executive power at provincial level. Interesting is the role of defining the functioning of the Empire's Political Charter, but not defining its structure, which was already pre-existing. In this pyramidal model, the hierarchical principle is rooted in the structuring of the state, which in practice makes the Constitution lose its leading role in the government mechanism.

Brazil during the validity of the Constitution of 1824 was divided into provinces. In unitary States, provincial division is a mode of administrative, not political, territorial decentralization. Initially administrative, this decentralization can become political, leading the centralized unitary state to become decentralized or regional unitary State.

Internally in the Provinces, the Municipality was a mere administrative division. They had their economic and municipal government exercised by a City Council (art. 167 to 169), with characteristics similar to the European municipalities or communes. Different situations of an important autonomous institutional figure at the municipal level, which represented the viability of the national state: the judge of peace.

According to Dolhnikoff ${ }^{9}$, the justice of the peace in Brazil concentrated great local power in the early years of the Empire. With functions that did not depend on the imperial government, the peace judges were elective positions, usually held by farmers of the regions, with great power and influence in the municipalities ${ }^{10}$. It is possible to observe with more emphasis after the adoption of the Criminal Procedure Code of $1832^{11}$.

The justice of the peace represented the liberal project of expansion and consolidation of the territory, with the authority exercised autonomously in the localities. Liberal federalism had as its project to reinforce provincial autonomy through municipal autonomies in order to seek an "arrangement that would combine and reconcile autonomy with a strong bond with the national State" ${ }^{\prime \prime}$.

As $\operatorname{Coser}^{13}$ notes, the existence of the post of judge of peace was crucial for the federative monarchy, which was from the outset the target of criticism from centralizers such as the Viscount of Uruguay. According to him, the Federalists' position was that the institutions needed to give citizens the possibility to be more actively involved in local affairs. Thus, "the election of the district justice in direct election without the need for training prerequisites was the most

${ }^{6}$ Pimenta Bueno, J.A. (1857). Direito Público Brazileiro e Analyse da Constituição do Império. Rio de Janeiro: Typographia Imp. e Const. de J. Villeneuve \& C.

${ }^{7}$ Gilissen, J. (1995). Introdução Histórica ao Direito. 2 ed. Tradução de Antonio Manuel Hespanha e L.M. Macaísta Malheiros. Lisboa: Fundação Calouste Gulbenkian.

${ }^{8}$ Elazar, D. J. (1997). Constrasting Unitary and Federal Systems. International Political Science Review. Camberra, v. 18, n. 3, p. 237-251.

${ }^{9}$ Dolhnikoff, M. (2007). O pacto imperial: origens do federalismo no Brasil. São Paulo: Globo, p. 83.

${ }^{10}$ Dolhnikoff, M. (2007), op. cit., p. 85.

${ }^{11}$ Dolhnikoff, M. (2007), op. cit., p. 83.

${ }^{12}$ Dolhnikoff, M. (2007), op. cit., p. 84.

${ }^{13}$ Coser, I. (2008). Visconde do Uruguai: Centralização e Federalismo no Brasil - 1823-1866. Belo Horizonte, Rio de Janeiro: UFMG, IUPERJ, p. 233. 
effective way of bringing the active citizen closer to public affairs" ${ }^{, 14}$.

Imperial Brazil concentrated all essential functions in one center; the four powers of the empire existed only at the national level. Decentralization was purely administrative. With the centralizing policy of Dom Pedro I, expressed in the text of the Constitution of 1824, there was a federative reaction, since the provincial leaders sought greater autonomy and consequently less subordination to the Imperial Capital. The most significant of the reactions was the failed attempt to proclaim a federal republic centered in the Province of Pernambuco, revolutionary separatist movement known as the Confederation of Ecuador, federal State eponymous independent if it had been successful.

The political tensions during the reign of Dom Pedro I had among their motives an intense debate between liberals and conservatives about the political decentralization of state power, which was better defined after 1831 with the emergence of the Liberal and Conservative Parties. After the abdication of the emperor in the same year, the federal project back to gain momentum and leads to a number of projects of administrative and political reforms during the Regency (1831-1840).

\section{The Additional Act of 1834}

The regency period in Empire Brazil was quite busy and, among such tribulations, the outbreak of conflicts in some provinces. Moreover, in Parliament, there was a confrontation between liberals and conservatives for the conciliation of centralism and federalism.

After the abdication of Dom Pedro I, a provisional triune regency was appointed. The three regents were Senator Nicolau Pereira de Campos Vergueiro, General Francisco de Lima e Silva and former Justice Minister José Joaquim Carneiro de Campos. This regency aimed to carry out a significant sociopolitical reform.

In the same year 1831, two laws were essential for the decentralization of central power in that period. The Law of June 6, 1831 gave the judges of peace the power to appoint block delegates at the municipal level. In the same year 1831, two laws were essential for the decentralization of central power in that period. The Law of June 6,1831 gave the judges of peace the power to appoint block delegates at the municipal level. In turn, the Law of June 14, 1831 reduced the powers of the Regency and strengthened the Parliament.

The apex of decentralization, as a clear manifestation of the presence of federalism in Brazil (federalism as a sociopolitical concept), is observed with the enactment of Law No. 16 of August 12, 1834, better known as the "Additional Act of 1834". Product of a radical project of federalist monarchy proposed by the liberals ${ }^{15}$, the result was a softening of the initial proposal, although very significant.

There was an effective affirmation of provincial autonomy in several aspects ${ }^{16}$. The most significant of these was the extinction of the General Provincial Councils and their replacement by the Provincial Legislative Assemblies. With this new body in each Province - with the electoral procedure established by the same Act -, there is a remarkable decentralization of legislative competence, which previously belonged only to the General Assembly.

The competence of the Provincial Assemblies excluded the legislative interference of the General Assembly in eminently provincial matters. Comparing these competences of the Provincial Assemblies established in Article 10 of the Additional Act with the attributions of the legislative power prescribed by Article 13 of the Constitution of 1824, the establishment of residual competences for the General Assembly, leaving the Provincial Assemblies an exhaustive list of exclusive powers.

The Additional Act of 1834 created a division of previously nonexistent legislative powers, as it was the responsibility of the General Assembly, pursuant to Article 15, VIII, of the Constitution of 1824: "to make Laws, interpret them, suspend them, and repeal them". The distribution of legislative powers appears as a centrifugal force for the operation of regential Brazil as a decentralized, albeit formally unitary State. For Dolhnikoff, although the term federative monarchy was abolished from the text by the senators, "the division of powers between central and provincial governments remained, with a significant degree of autonomy from the latter"17.

Despite the unitary State, the Additional Act of 1834 constitutionally created legislative power at provincial level. It was an authentic makeover. In commenting on its nature, Pimenta Bueno comments that "the provincial legislative power is not a delegation of national sovereignty, it is not a general power, but a purely provincial representation, and authorized

\footnotetext{
${ }^{14}$ Coser, I. (2008). op. cit., p. 237.

${ }^{15}$ Dolhnikoff, M. (2007). op. cit., p. 93-94.

${ }^{16}$ Dolhnikoff, M. (2007). op. cit., p. 97.

${ }^{17}$ Dolhnikoff, M. (2007). op. cit., p. 95.
} 
only for the mission that the fundamental laws of the State are entrusted to it" ${ }^{\prime 18}$. The federalist project failed to approve executive power at this level, although it was successful in promoting the exercise of legislative power at the provincial level.

The scenario created with the reform of 1834 had interesting theoretical repercussions. Pedro Calmon ${ }^{19}$, for example, understands that this reform created an unprecedented constitutional system: the semifederalism (or quasifederalism). The provinces, according to the author, "were recognized as autonomous entities and had political representation in the local Legislative Assembly, their independent treasury, municipal justice, their own jurisdiction. They just did not elect presidents, which they apparently lacked to be States in federation",20.

In the nineteenth century, Tavares Bastos ${ }^{21}$ denounced the resulting muddle of this system: reform would have led to a great inefficiency in the provincial administration, as the people would elect members of the Provincial Assembly to legislate in accordance with the competences brought by Article 10 of the 1834 Act. However, the execution of the laws was the responsibility of Presidents of the Provinces who had no commitment to enforce laws of local interest. This mismatch of local laws being enforced by the imperial executive power - of which the Presidents were a part - causes disorder and anarchy due to political disputes ${ }^{22}$.

On the other hand, the centralizing argument was that the Additional Act of 1834 enhanced the powers of local elites and thus could control the application of the law $^{23}$. The way to avoid the local particularism was the uniform application of laws across imperial territory ${ }^{24}$. Centralization, in this sense, would have the objective of elaborating and implementing Justice ${ }^{25}$, a situation in which the entire population of the empire would be equalized and protected from the absurd provincial laws ${ }^{26}$.

The federalist project during the Empire suffered a severe blow with the passing of the Interpretation Act of 1840, which stated how certain terms used in the Act of 1834 should be understood. Although it appears to be the cancellation of liberal achievements from 1832 onwards the true purpose of this conservative review was "the centralization of the judiciary, granting the central government exclusivity in decisions about general employment, while provincial government reserved decisions on provincial and municipal employment"27.

Viscount of Uruguay states that the interpretation that the Act of 1834 was intended only to facilitate the administration of the central government, not to confer political power on the provinces.

The purpose of the additional act (holy and just purpose) was to place sufficient power, sufficient means, and sufficient authority in the provinces to be able to carry out certain provincial business without the long delays of one center, since if they contained the streak outlined by the Constitution, they would be independent even from the General Assembly ${ }^{28}$.

This position of Uruguay demonstrates the centralizing view, which understood that a monarchy was incompatible with the federal state form. Indeed, Imperial Brazil seems to have functioned as a federation in practice, albeit formally unitary.

Such debates about centralization and decentralization in the Empire of Brazil had as their main question the degree of autonomy that the Provinces should have in relation to the Capital, Rio de Janeiro (transformed into Neutral Municipality also by the Additional Act of 1834). It is a fundamental question of the study of federalism. As a sociological concept, the presence of federalism in a country is independent of constitutional law.

\footnotetext{
${ }^{18}$ Pimenta Bueno, J.A. (1857). op. cit., p. 153.

${ }^{19}$ Calmon, P. (2002). História Social do Brasil: Volume 2 - Espírito da Sociedade Imperial. São Paulo: Martins Fontes, p. 185 .

${ }^{20}$ Calmon, P. (2002). op. cit., p. 185.

${ }^{21}$ Tavares Bastos, A. (1870). op. cit., p. 125.

${ }^{22}$ Tavares Bastos, A. (1870). op. cit., p. 126.

${ }^{23}$ Coser, I. (2008). op. cit., p. 238.

${ }^{24}$ Coser, I. (2008). op. cit., p. 240.

${ }^{25}$ Coser, I. (2008). op. cit., p. 242.

${ }^{26}$ Coser, I. (2008). op. cit., p. 233.

${ }^{27}$ Dolhnikoff, M. (2007). op. cit., p. 153.

${ }^{28}$ Uruguai, Paulino José Soares de Souza, Visconde de. (1865). op. cit., p. 27.
} 


\section{Conclusions}

Viewed as a sociological concept, federalism was present in social relations during Imperial Brazil, as shown by this research. As a concept not dependent on the federal state, federalism emerged in Brazil due to numerous factors such as the geographical distribution of power centers, the territorial extension and the sense of belonging of a certain population to their region, even if held together under the aegis of a same sovereign order.

As widely shown in the works of Oliveira Vianna (during the first half of the twentieth century), the Brazilian people did not develop in a homogeneous way. Brazil is not a nation, with its developed public right to be thinking of a state project. Instead; Brazil developed as a multiplicity of nuclei, based on some relationships, which Oliveira Vianna will call "feudal clans" and "parental clans". With independence in 1822, the "electoral clans" emerge and shape Brazil so that politics is thought of in isolation in ganglia, not as a whole.

The Additional Act of 1834 allowed a considerable decentralization of Brazilian political relations, in order to approach the decentralized configuration of its society. Through the innovations of the 1834 Act during the Regency period, there is a huge centrifugal movement in the relations between the provinces and Rio de Janeiro, which leads to a reflection on the gradual development of federalism in Brazil, even though it had not been. legally imposed by Decree No. 1 of November 15, 1989, at the time of the Proclamation of the Republic.

\section{References}

Calmon, P. (2002). História Social do Brasil: Volume 2 - Espírito da Sociedade Imperial. São Paulo: Martins Fontes.

Coser, I. (2008). Visconde do Uruguai: Centralização e Federalismo no Brasil - 1823-1866. Belo Horizonte, Rio de Janeiro: UFMG, IUPERJ.

Dolhnikoff, M. (2007). O pacto imperial: origens do federalismo no Brasil. São Paulo: Globo.

Elazar, D. J. (1997). Contrasting Unitary and Federal Systems. International Political Science Review. Camberra, 18(3), 237-251. https://doi.org/10.1177/019251297018003002

Gilissen, J. (1995). Introdução Histórica ao Direito. 2 ed. Tradução de Antonio Manuel Hespanha e L.M. Macaísta Malheiros. Lisboa: Fundação Calouste Gulbenkian.

Livingston, W. S. (1952). A Note on the Nature of Federalism. Political Science Quarterly, 67(1)1, 81-95. https://doi.org/10.2307/2145299

Liziero, L. (2017). Por um Estado Federal Assimétrico. Insigth Inteligência. Rio de Janeiro, 78, 132-152.

Neves, M. (2018). A Constitucionalização Simbólica. 3 ed. São Paulo: Martins Fontes.

Neves, M. (2018). Constituição de Direito na Modernidade Periférica. São Paulo: Martins Fontes.

Pimenta Bueno, J. A. (1857). Direito Público Brazileiro e Analyse da Constituição do Império. Rio de Janeiro: Typographia Imp. e Const. de J. Villeneuve \& C.

Tavares Bastos, A. (1870). A Provincia: estudo sobre a Descentralisação no Brazil. Rio de Janeiro: B.L.Garnier.

Uruguai, Paulino José Soares de Souza, Visconde de. (1865). Estudos Praticos sobre a Administração das Provincias no Brasil. Rio de Janeiro, B.L. Garnier.

Vianna, O. (1987). Instituições Políticas Brasileiras, 2: Metodologia do Direito Público. Belo Horizonte: Itatiaia; São Paulo: EDUSP; Niteroi: EDUFF.

\section{Copyrights}

Copyright for this article is retained by the author(s), with first publication rights granted to the journal.

This is an open-access article distributed under the terms and conditions of the Creative Commons Attribution license which permits unrestricted use, distribution, and reproduction in any medium, provided the original work is properly cited. 